\title{
The Multiple Criteria Assessment on the selected vegetable oils for the lubricating engine
}

\author{
Małgorzata Malinowska ${ }^{1 *}$ and Lukasz Muślewski ${ }^{1}$ \\ ${ }^{1}$ Bydgoszcz University of Science and Technology, Faculty of Mechanical Engineering, Al. prof. S. \\ Kaliskiego 7 85-789 Bydgoszcz, Poland
}

\begin{abstract}
Vegetable oils are considered to be an alternative and environmentally friendly resource of lubricants. Suitable for almost all industrial applications. They are obtained from natural raw materials, which are renewable and non-toxic to humans, living organisms, and the environment. Chemically, green oils are triacylglycerols with varying fatty acids compositions depending on the plant or seed, the crop, the growing conditions and the season, etc. The conducted research concerning matching the proper of type of vegetable oil to lubrication of the engine. The main objectives of engine oil have been drawn to the attention. To project of assessment has selected four roles of engine oil: lubrication, cooling, corrosion protection, and others (including oxidative stability, ash content, saponification value, and foam property). Each objective is described by a couple of detailed parameters of lubricants (for example viscosity index, coefficient of friction, wear scar diameter, pour point, cloud point, melting point, smoke point, flash point, iodine value, thermal conductivity, specific heat capacity, density, water content, acid number, anti-corrosion properties, etc.). In the evaluation process, AHP (Analytic Hierarchy Process) methods were used to determine the weights of individual criteria. Everything creates multiple criteria assessment of green oil. As a result of the multi-criteria assessment, most high scores have soybean oil, linseed oil, cottonseed oil, and olive.
\end{abstract}

\section{Introduction}

Lubricating oils are commonly used in automotive, industrial, process, and marine applications. In order to reduce consumption of energy by means of minimizing friction and wear of moving surfaces, cooling of elements, and extend the service life of mechanical devices [1]. In general, lubricants are composed of base oils and adjusted additives. Currently, a lot of bases are mineral oils derived from crude oil. However, the crude reserve is depleting and the environmental concern about the damaging impact of mineral oil is growing. There is a diligent demand for promising alternatives for mineral base stocks, which may be vegetable oils [2].

\footnotetext{
* Corresponding author:malgorzata.malinowska@pbs.edu.pl
} 
The use of lubricants derived from natural raw (seeds, plants) has been in practice for many years. However, this idea was neglected due to the discovery of the aforementioned crude oil and the availability of low-cost mineral oils. Green oils are a quite good solution for commercial lubricants, since they retain a lot of technical properties of mineral oils.

The most important attributes of natural lubricants are non-toxicity, non-mutagenic, biodegradability. They have good lubricity properties, high lubricity index, and high flash point, etc. $[3,4]$.

They are recommended for lubrication of the engine: soybean, olive, and coconut oil $[1,5]$. However, there is no broad explanation for such choices. This paper used multicriteria assessment to select the best green oil from 9 popular in Poland types of bio-oils (rapeseed oil, castor oil, soybean oil, sunflower oil, linseed oil, palm oil coconut oil, and olive). On the basis of the main roles of lubricants in the engine, and selected 24 detailed parameters.

\section{Vegetable oil}

The vegetable oils are called green oils, natural oils, bio-oils, plant oils, or natural esters [6]. Bio-lubricant is defined as a lubricant obtained from natural raw materials, which are renewable and non-toxic for humans, living organisms, and environment. From a technical point of view, natural esters display very good physicochemical properties, such as high viscosity indexes and flash points as well as good resistance to shear [1].

Chemically, plant oils are completely different from commercial mineral or synthetic oils. The major element of plant oils (approximately 98\%) is triacylglycerols with varying fatty acids composition depending on the plant or seed, the crop, the growing conditions and the season, etc. The rest components of green oils are diacylglycerols, monoacylglycerols, fatty acids, sterols, and tocopherols. Most of these minor elements are deleted in processing, and some are valuable by products $[4,7]$.

The variety of plant oils allows them to be used in different industrial applications, including as biofuels, transmission fluids, metal casting, printing, inks, paints, coatings, disinfectants, greases, hydraulic fluids, etc.In table 1 shows the selected popular type of green oils with possible industrial applications.

Table 1. Selected vegetable oils developed for industry applications $[1,5]$.

\begin{tabular}{|c|c|c|}
\hline No. & Type of oil & Application \\
\hline 1. & Rapeseed oil & $\begin{array}{c}\text { Chain saw bar lubricants, air compressor-farm equipment, } \\
\text { greases, hydraulic fluids }\end{array}$ \\
\hline 2. & Castor oil & Gear lubricants, greases \\
\hline 3. & Soybean oil & $\begin{array}{c}\text { Engine oils, transmission fluids, biodiesel fuel, metal } \\
\text { casting/working, printing inks, paints, coatings, disinfectants, } \\
\text { plasticisers, hydraulic oils }\end{array}$ \\
\hline 4. & Sunflower oil & Greases, diesel fuelsubstitutes \\
\hline 5. & Linseed oil & Coating, paints, lacquers, varnishes, Stains \\
\hline 6. & Palm oil & Rolling lubricant,-steel industry, grease \\
\hline 7. & Coconut oil & Engine oils, Gas engine oils \\
\hline 8. & Cottonseed oil & Bio fuels \\
\hline
\end{tabular}




\begin{tabular}{|l|l|l}
\hline 9. & Olive & Engine oils, Automotive lubricants \\
\hline
\end{tabular}

According to the authors of the cited table 1 [1,5] for engine applications, the best choice may be soybean, olive, coconut oil. However, there is no broad explanation for such choices. In the next part of the paper, the multiple criteria assessment of vegetable oils is based on the most important objectives of engine oil.

However, the use of green oil to make lubricants is problematic, since most connect with the food chain, thereby causing speculation regarding the costs of natural oils and producing social imbalances and strong growth prices [1].

\section{ENGINE OIL}

Lubricating oil plays a key role in engines by diminishing friction and wear of moving pieces, inhibiting corrosion of the engine system, improving sealing, and cooling the engine [8]. In engine systems, lubricants must operate under variable pressure and temperature conditions and have to be stable to prolonged exposure to contaminating acids, which can cause progressive deterioration of the lubricant $[1,9]$.

In general, a good lubricant should have high viscosity index (VI), high flash point, low pour point, high oxidation, and thermal stability, etc., as shown in Fig. 1.

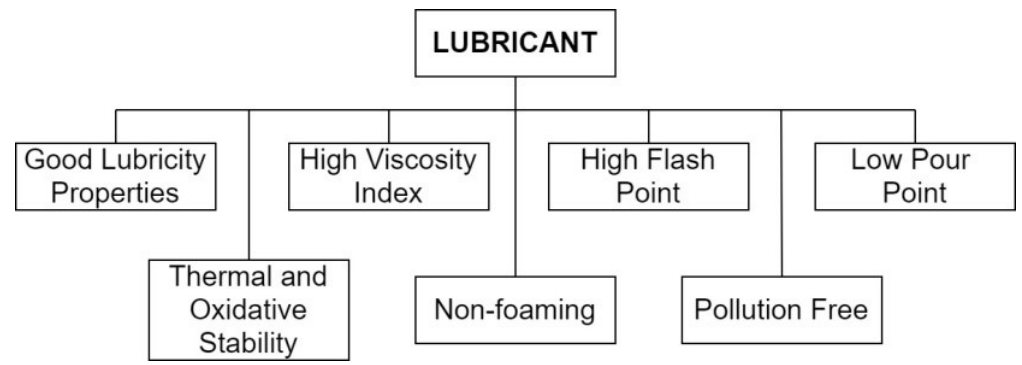

Fig. 1. Properties of good engine oil.

Listed in figure 1, the properties of good engine oil have been divided into 4 main objectives that motor oil should fulfill:

1. Lubrication,

2. Cooling,

3. Corrosion protection,

4. Other (incl. oxidation stability, resistance to foaming, contents of pollutants, etc.).

\section{MULTIPLECRITERIA ASSESMENT OF VEGATABEL OIL}

According to the division presented in point 3, criteria have been designed on the basis of which selected engine oils will be assessed (table 2). Each of the functions has been assigned appropriate detailed parameters that characterize the selected roles. In the evaluation process, AHP (Analytic Hierarchy Process) methods were used to determine the weights of individual criteria [10].

Table 2.The criterion weight for individual objectives.

\begin{tabular}{|l|l|l|}
\hline No. & Objective & Criterion Weight by AHP \\
\hline
\end{tabular}




\begin{tabular}{|l|c|c|}
\hline 1. & Lubrication & 0,5068 \\
\hline 2. & Cooling & 0,2641 \\
\hline 3. & Corrosion Protection & 0,1428 \\
\hline 4. & Others & 0,0863 \\
\hline
\end{tabular}

\subsection{Lubrication}

The basic role of engine oil is to lubricate the surface of engine moving parts, which are in friction. It thus reduces friction, which tends to increase wear and tear of engine elements. In order to evaluate this role have been used: viscosity index, viscosity at 40 and 100 degrees Celsius, coefficient of friction, wear scar diameter, pour point, cloud point, melting point, smoke point, flash point, and iodine value (table 3).

Table 3. The criterion weight for parameters describing lubricating properties.

\begin{tabular}{|c|c|c|c|c|}
\hline No. & Parameter & Unit & $\begin{array}{c}\text { Criterion } \\
\text { Weight } \\
\text { by AHP }\end{array}$ & Comment \\
\hline 1. & $\begin{array}{l}\text { Viscosity index } \\
\text { (VI) }\end{array}$ & - & 0,2555 & \multirow{3}{*}{$\begin{array}{l}\text { Viscosity is the most important property } \\
\text { of oil.It defined as the resistance of oil to } \\
\text { flow. The possible range of VI [1]: } \\
\text { VI }<35-\text { low, } \\
35<\mathrm{VI}<80 \text { - medium, } \\
80<\mathrm{VI}<110 \text { - high, } \\
\text { VI }>110 \text {-very high. }\end{array}$} \\
\hline 2. & Viscosity at $40^{\circ} \mathrm{C}$ & $\begin{array}{c}\mathrm{cSt} \text { or } \\
\mathrm{mm}^{2} / \mathrm{s} \text { or } \\
\mathrm{Pa}^{*} \mathrm{~s}\end{array}$ & \multirow{2}{*}{0,1390} & \\
\hline 3. & $\begin{array}{l}\text { Viscosity at } \\
100^{\circ} \mathrm{C}\end{array}$ & $\begin{array}{c}\mathrm{cSt} \text { or } \\
\mathrm{mm}^{2} / \mathrm{s} \text { or } \\
\mathrm{Pa}^{*} \mathrm{~s}\end{array}$ & & \\
\hline 4. & $\begin{array}{l}\text { Coefficient of } \\
\text { friction }\end{array}$ & - & 0,0961 & \multirow{2}{*}{$\begin{array}{l}\text { The tribological properties of lubricants } \\
\text { could be evaluated by a lot of values. } \\
\text { However, the most popular are wear scar } \\
\text { diameter and coefficient of friction, using } \\
\text { a four-ball tester. }\end{array}$} \\
\hline 5. & $\begin{array}{l}\text { Wear scar } \\
\text { diameter }\end{array}$ & $\mathrm{mm}$ & 0,0961 & \\
\hline 6. & Pour point & ${ }^{\circ} \mathrm{C}$ or $\mathrm{K}$ & 0,0465 & \multirow{5}{*}{$\begin{array}{l}\text { The lubrication process has to take place } \\
\text { in the entire operating temperature range } \\
\text { of the engine, therefore it is important to } \\
\text { determine the low (pour, cloud, and } \\
\text { melting point) and high temperature } \\
\text { (smoke and flash point) properties. }\end{array}$} \\
\hline 7. & Cloud point & ${ }^{\circ} \mathrm{C}$ or $\mathrm{K}$ & 0,0465 & \\
\hline 8. & Melting point & ${ }^{\circ} \mathrm{C}$ or $\mathrm{K}$ & 0,0465 & \\
\hline 9. & Smoke point & ${ }^{\circ} \mathrm{C}$ or $\mathrm{K}$ & 0,0465 & \\
\hline 10. & Flash point & ${ }^{\circ} \mathrm{C}$ or $\mathrm{K}$ & 0,1994 & \\
\hline 11. & Iodine value (IV) & $\mathrm{gI} / 100 \mathrm{~g}$ & 0,027618 & $\begin{array}{c}\text { Indicator of the number of unsaturation } \\
\text { in the triglyceride.This parameter gives } \\
\text { an indication of green oil ability to dry in } \\
\text { the presence of oxygen in the air. } \\
\text { The possible range of IV [11]: } \\
\text { IV }<110 \text { - non-drying oil, } \\
110<\text { IV }<150 \text { - semi-drying oil, } \\
\text { IV }>150 \text { - drying oil. }\end{array}$ \\
\hline
\end{tabular}




\subsection{Cooling}

The energy is lost through combustion, and the friction between parts causes the engine temperature to rise. The lubrication provided by the engine oil helps to release the heat through the lubrication system. It supports the coolant, which only cools certain elements of the engine. The parameters describing the ability to cool are thermal conductivity, specific heat capacity, viscosity at the lowest known temperature, pour point, density (table 4).

Table 4. The criterion weight for parameters describing cooling properties.

\begin{tabular}{|c|c|c|c|c|}
\hline No. & Parameter & Unit & $\begin{array}{c}\text { Criterion } \\
\text { Weight }\end{array}$ & Comment \\
\hline 12. & Thermalconductivity & $\mathrm{W} / \mathrm{m} * \mathrm{~K}$ & 0,1667 & \multirow{4}{*}{$\begin{array}{l}\text { These values significantly affect the } \\
\text { transfer of heat, which is crucial from the } \\
\text { point of view of heat dissipation to the } \\
\text { environment. } \\
\text { Information on the viscosity at different } \\
\text { temperatures (especially low). The high } \\
\text { viscosity leads to a decrease in cooling } \\
\text { efficiency. }\end{array}$} \\
\hline 13. & $\begin{array}{l}\text { Specific heat } \\
\text { capacity }\end{array}$ & $\mathrm{J} / \mathrm{kg} * \mathrm{~K}$ & 0,1667 & \\
\hline 14. & $\begin{array}{l}\text { Viscosity at lowest } \\
\text { known temperature }\end{array}$ & $\begin{array}{c}\mathrm{cSt} \text { or } \\
\mathrm{mm}^{2} / \mathrm{s} \text { or } \\
\mathrm{Pa}^{*} \mathrm{~s}\end{array}$ & 0,1667 & \\
\hline 15. & Pour point & ${ }^{\circ} \mathrm{C}$ or $\mathrm{K}$ & 0,1667 & \\
\hline 16. & Density & $\begin{array}{l}\mathrm{kg} / \mathrm{m}^{3} \text { or } \\
\mathrm{g} / \mathrm{cm}^{3}\end{array}$ & 0,1667 & $\begin{array}{l}\text { High density enables use as a storage } \\
\text { medium. }\end{array}$ \\
\hline
\end{tabular}

\subsection{Corrosion Protection}

Fuel combustion generates corrosive acid that can damage the metal surfaces in the engine. With the special additives added to lubricants, corrosion is delayed. Over time, and in contact with oxygen, engine oil may oxidize and no longer play its corrosion inhibiting role. In order to evaluate this role have been used: water content, acid number, anti-corrosion properties, iodine value (table 5).

Table 5. The criterion weight for parameters describing corrosion protection properties.

\begin{tabular}{|c|c|c|c|c|}
\hline No. & Parameter & Unit & $\begin{array}{l}\text { Criterion } \\
\text { Weight }\end{array}$ & Comment \\
\hline 17. & Water content & $\begin{array}{l}\% \text { or } \\
\text { ppm }\end{array}$ & 0,2064 & $\begin{array}{l}\text { The presence of water can increase the } \\
\text { oxidation rate. The water contained in the } \\
\text { oils is considered a highly hazardous } \\
\text { pollutant. }\end{array}$ \\
\hline 18. & Acid number & $\begin{array}{c}\mathrm{mg} \\
\mathrm{KOH} / \mathrm{g}\end{array}$ & 0,3642 & $\begin{array}{l}\text { The acidity makes bio-oil very corrosive and } \\
\text { extremely severe at high temperature. }\end{array}$ \\
\hline 19. & $\begin{array}{l}\text { Anti-corrosion } \\
\text { properties }\end{array}$ & - & 0,3642 & $\begin{array}{l}\text { The most popular (and easy) method to test } \\
\text { this parameter is copper strip corrosion. The } \\
\text { range of results test }[12] \text { : } \\
1 \mathrm{a}, 1 \mathrm{~b}-\text { slight tarnish, } \\
2 \mathrm{a}-2 \mathrm{e}-\text { moderate tarnish, } \\
3 \mathrm{a}, 3 \mathrm{~b}-\text { dark tarnish, } \\
4 \mathrm{a}-4 \mathrm{~d}-\text { corrosion. }\end{array}$ \\
\hline 20. & Iodinevalue (IV) & $\mathrm{gI} / 100 \mathrm{~g}$ & 0,0652 & $\begin{array}{l}\text { This parameter gives an indication of green } \\
\text { oil ability to dry in the presence of oxygen in } \\
\text { the air. }\end{array}$ \\
\hline
\end{tabular}




\subsection{Others}

This group listed four parameters. Surface tension, describing the ability to build foam. Next oxidation stability, ash content and saponification value - specific number for vegetable oils.

Table 6. The criterion weight for parameters describing others important properties of engine oils.

\begin{tabular}{|c|c|c|c|c|}
\hline No. & Parameter & Unit & $\begin{array}{c}\text { Criterion } \\
\text { Weight }\end{array}$ & Comment \\
\hline 21. & $\begin{array}{c}\text { Surface tension at } \\
20^{\circ} \mathrm{C}\end{array}$ & $\mathrm{mN} / \mathrm{m}$ & 0,2785 & $\begin{array}{c}\text { The high surface tension is responsible } \\
\text { for the formation of foam [13]. }\end{array}$ \\
\hline 22. & Ash content & $\begin{array}{c}\% \text { or } \\
\mathrm{ppm}\end{array}$ & 0,1312 & $\begin{array}{c}\text { The presence of ash in oil can cause } \\
\text { erosion, corrosion, and formation of } \\
\text { hard deposits. }\end{array}$ \\
\hline 23. & $\begin{array}{c}\text { Saponification } \\
\text { value }\end{array}$ & $\mathrm{KOH} / \mathrm{g}$ & 0,0656 & $\begin{array}{c}\text { A higher value for a given oil specifies } \\
\text { a larger amount of smaller molecular } \\
\text { weight fatty acids [14]. }\end{array}$ \\
\hline 24. & $\begin{array}{c}\text { Oxidation } \\
\text { stability, } 110^{\circ} \mathrm{C}\end{array}$ & $\mathrm{h}$ & 0,5247 & $\begin{array}{c}\text { Oxidative stability depends on the } \\
\text { vegetable oil composition and the } \\
\text { conditions the sample is subjected to. } \\
\text { Resulting in chemical, and physical } \\
\text { properties changes [15]. }\end{array}$ \\
\hline
\end{tabular}

\section{ASSESSMENT OF THE SELECTED VEGETABLE OILS}

In compliance with the criterion weights for four groups describing the main roles of lubricants in the engine, presented in point 4. Selected nine green oils (rapeseed oil, castor oil, soybean oil, sunflower oil, linseed oil, palm oil coconut oil, and olive) were evaluated. These green oils are popular and commonly used in Poland. Parameter values have been collected from many papers of other authors $[1,7,9,13,16-24]$ and own research $[4,6]$.

At the same time, it should be remembered that the main criterion for assessing individual oils is their performance in the context of the most important operating parameters, which should be the basis for their classification [25-41].

Based on the detailed calculations, the results for each objective are listed in table 7 and 8. The sum of the results from the 4 roles gives the overall score for the multiple criteria assessment. Analyzing the obtained scores, soybean oil has the best lubrication properties. Castor oil turned out to be top for cooling. Linseed oil will protect the engine from corrosion. Coconut oil is most appropriate in terms of oxidative stability and ash content.

Table 7. The finale calculation of multi-criteria assessment for rapeseed oil, castor oil, soybean oil and sunflower oil.

\begin{tabular}{|c|c|c|c|c|c|c|c|c|c|}
\hline & \multirow{2}{*}{ Weight } & \multicolumn{2}{|c|}{ Rapeseed oil } & \multicolumn{2}{c|}{ Castor oil } & \multicolumn{2}{c|}{ Soybean oil } & \multicolumn{2}{c|}{ Sunflower oil } \\
\hline Lubrication & 0,5068 & 4,3266 & 2 & 5,174 & 4 & 6,379 & 9 & 5,666 & 6 \\
\hline Cooling & 0,2641 & 3,3336 & 3 & 6,167 & 9 & 3,834 & 5 & 3,000 & 2 \\
\hline $\begin{array}{c}\text { Corrosion } \\
\text { Protection }\end{array}$ & 0,1428 & 6,1898 & 9 & 2,663 & 3 & 5,227 & 7 & 4,859 & 6 \\
\hline Others & 0,0863 & 6,296 & 7 & 3,296 & 3 & 4,900 & 5 & 3,016 & 2 \\
\hline \multicolumn{2}{|c|}{} & $\mathbf{3 , 6 9 5}$ & $\mathbf{5 , 0 9 1 5}$ & $\mathbf{7 , 3 1}$ & $\mathbf{4 , 5 9 8 2}$ \\
\hline
\end{tabular}


Table 8. The finale calculation of multi-criteria assessment for linseed oil, palm oil, coconut oil, cottonseed oil and olive.

\begin{tabular}{|c|c|c|c|c|c|c|c|c|c|c|c|}
\hline & Weight & \multicolumn{2}{|c|}{ Linseed oil } & \multicolumn{2}{|c|}{ Palm oil } & \multicolumn{2}{|c|}{ Coconut oil } & \multicolumn{2}{c|}{ Cottonseed oil } & \multicolumn{2}{|c|}{ Olive } \\
\hline Lubrication & 0,5068 & 5,497 & 5 & 4,400 & 3,000 & 3,677 & 1 & 6,360 & 8 & 5,673 & 7 \\
\hline Cooling & 0,2641 & 6,167 & 9 & 2,000 & 1,000 & 5,167 & 7 & 3,500 & 4 & 5,000 & 5 \\
\hline $\begin{array}{c}\text { Corrosion } \\
\text { Protection }\end{array}$ & 0,1428 & 5,244 & 8 & 2,522 & 2,000 & 3,744 & 5 & 3,636 & 4 & 1,495 & 1 \\
\hline Others & 0,0863 & 3,753 & 4 & 5,427 & 6,000 & 7,360 & 9 & 2,525 & 1 & 6,491 & 8 \\
\hline & & $\mathbf{6 , 3 9 9}$ & $\mathbf{2 , 5 8 8}$ & $\mathbf{3 , 8 5}$ & $\mathbf{5 , 7 6 8}$ & $\mathbf{5 , 7 0 1}$ \\
\hline
\end{tabular}

According to the multi-criteria assessment of green oils (table 7 and table 8), soybean oil with a score of 7.31, the best will fulfill the function of engine oil. The second-place has a linseed oil with a score of 6.399. The last place was taken by two cottonseed oil and olive, with very similar results (5.768 and 5.701 respectively). The general scores of mentioned four green lubricants are marked with gray.

Palm oil received the lowest score, 2.588. Coconut oil (presented in table 1 as a possible solution for engine oil) could have obtained much better results, but a high pour point causes a strong reduction in the overall rating. The high value of the pour point is crucial for the engine starting in winter conditions.

\section{CONCLUSION}

The crude reserve is depleting and the environmental concern about the damaging impact of mineral oil is growing. There is a diligent demand for alternatives for mineral base stocks, which may be vegetable oils. There are many types of vegetable oils, and they differ in chemical composition. The question remains, which of these a lot of types will be the most suitable for engine lubrication.

The paper shows a multiple criteria assessment of selected popular green oils. This assessment paid attention to four main roles of engine oil, they are lubrication, cooling, corrosion protection, and others (including oxidative stability, ash content, saponification value, and foam property). The author's assessment contains 24 detailed parameters of oils. The based on the collected values of parameters from own and other authors' research. Evaluated nine popular oils: rapeseed oil, castor oil, soybean oil, sunflower oil, linseed oil, palm oil coconut oil, and olive.

As a result of multi-criteria assessment it turned out that the most high scores have soybean oil, linseed oil, cottonseed oil and olive. The soybean and olive oils were known as prospective engine oils. The quite good result of linseed and cottonseed oil is surprising. Moreover, they have inedible sources. It is important due to social imbalances involved with deficiencies of food.

Therefore, it is recommended a make wide own research usability this type of oils (linseed oil and cottonseed oil) to application for lubrication of the engine. It is also will allow to grade quality of prepared multi-criteria assessment.

This investigation is significant in the present context of increasing global environmental pollution and decreasing crude sources. The crucial benefits of green lubricants are their high 
biodegradability, renewable resource, and low toxicity. On the other hand, they are more expensive than mineral oils and some of them have edible sources. However, it should be research conducted possibility of replace the traditional mineral oils with bio-based oil. Especially need to pay attention to two aspects, economy and ecology.

\section{References}

1. T.Y. Woma, S.A. Lawal, A.S.Abdulrahman, M. A. Olutoye and M. M. Ojapah, VegetableOil Based Lubricants: Challenges and Prospects, inTribology Online, 14, No. 2/70 (2019)

2. D. Zheng, X. Wang, M. Zhang, Z. Liu, Ch. Ju, Anticorrosion and lubricating properties of a fully green lubricant, in Tribology International 130 (2019)

3. H. M. Mobarakn ENM, H. H. Masjuki, M. A. Kalam, K. A. H. Al Mahmud, M. Habibullah, A. M. Ashraful, The prospects of biolubricants as alternatives in automotive applications, in Renewable and Sustainable Energy Reviews, 33 (2014)

4. M. Malinowska, The full or partial replacement of commercial marine engine oil with bio oil, on the example of linseed oil, in Journal of KONES, 26, No.3 (2019)

5. YM. Shashidhara, SR. Jayaram, Vegetable oil as a potential cutting fluid - an evolution, in TribolInt 43(2010)

6. M. Malinowska, The full or partial replacement of mineral marine engine oil with vegetable oil. on the example of rapeseed oil, inJournal of KONES, 24, No.1 (2017)

7. N. Salih, J. Salimon, A Review on Eco-Friendly Green Biolubricants from Renewable and Sustainable Plant Oil Sources, inBiointerface Research in Applied Chemistry, 11, Issue 5 (2021)

8. D. Klamann, R.R. Rost, A.G.R.C. Esso, Lubricants and Related Products: Synthesis, Properties, Applications, International Standards, Verlag Chemie: Weinheim, Germany (1984).

9. J. A. Cecilia, D. Ballesteros Plata, R. M. Alves Saboya, F. M. Tavares de Luna, C. L. Cavalcante Jr. and E. Rodríguez-Castellón An Overview of the Biolubricant Production Process: Challenges and Future Perspectives, in Processes 2020, 8, 257 (2020)

10. T.L. Saaty, The Analytic Hierarchy Process, Planning, Priority Setting and Resorce Allocation. Mc Graw-Hill, New York (1980)

11. O. Zovi, Functionalisation and photopolymerisation of linseed oil for the development of new materials without emissions of volatile organic compounds (VOCs), $\mathrm{PhD}$ Thesis, INSA de Rouen (2009)

12. ASTM D130 - Standard Test Method for Corrosiveness to Copper from Petroleum Products by Copper Strip Test

13. E.A., Melo-Espinosa, Y., Sanchez-Borroto, M., Errasti, R., Piloto-Rodriguez, R., Sierens, J., Roger-Riba,A.Christopher-Hansen, Surface tension prediction of vegetable oils using artificial neural networks and multiple linear regression, inEnergy Procedia, 57 (2014)

14. R. Sathiyamoorthi, G. Sankaranarayanan, M. Venkatraman, D. Babu Munuswamy, R. Ravisankar, Environment-friendly fuel Cymbopogonflexuosus: Analysis of fuel properties, performance, and emission parameters of a Direct Injection Compression Ignition research engine, in Heat transfer, 50, issue 7 (2021)

15. A. Adhvaryu, S.Z. Erhan, Z.S. Liu, J.M. Perez, Oxidation kinetic studies of oils derived from unmodified and genetically modified vegetables using pressurized differential 
scanning calorimetry and nuclear magnetic resonance spectroscopy, in Thermochim. Acta. 364 (2000)

16. A. Kulczycki, Modelowanie procesów w eksploatacji silników spalania wewnętrznego: konwencjonalne i alternatywne paliwa płynne w eksploatacji silników, Warszawa, (2018)

17. K. Gobinda, G. Pranab, K.S. Bragendra,Chemically Modified Vegetable Oils to Prepare Green Lubricants Lubricants, 44 (2017)

18. Xuan Nam Chu,Effect of Coconut Oil Acid Component on Material Durability and Corrosion in Fuel Supply System of Diesel Engines, inInternational Journal of Applied Engineering Research, 13, Number 10 (2018)

19. V. Vrabie, D. Scarpete, O. Zbarcea, Vegetable Oils as Alternative Fuels for new Generation of Biodiesel Engines: A Review, inScientific Proceedings. International Scientific-Technical Conference 105-109 (2016)

20. I. Stanciu, Viscosity index for oil used as biodegradable lubricant, in Indian Journal of Science \& Technology, 13 (2020)

21. J.N.Coupland, D.J. McClements,Physical properties of Liquid Edible oils, in JAOCS, 74, No.12 (1997)

22. Metrohm, Determination of free fatty acids (FFA) in edible oils with 859 Titrotherm

23. O.E.P. Tulcan, D.O. De Andrade, E.T. De Andrade, R.G. Pereira, Analysis of physical characteristics of vegetable oils, in Paper Presented at the CIGR- International Conference of Agricultural Engineering, Brazil. 31st August - 4th September (2008)

24. R. E. BooserTribology data handbook, CRC Press, Boca raton, New York (1997).

25. B. Landowski, Application of Markov decision process as a mathematical model of operation and maintenance process. p-ISSN: 1733-8670. Scientific Journals. Maritime University of Szczecin, 2010, 24(96) pp. 12-16 (2010)

26. B. Landowski, M. Baran, Analysis of selected results of engine oil tests, MATEC Web of Conferences 302, 01010 (2019), 18th International Conference Diagnostics of Machines and Vehicles, pp.1-7 (2019)

27. B. Landowski, M. Baran, Analysis of changes in the value of selected lubricant characteristics during use, MATEC Web of Conferences 302, 01009 (2019), 18th International Conference Diagnostics of Machines and Vehicles, pp.1-8 (2019)

28. M. Szyca, Aspekty transformacji eksploatacyjnej warstwy wierzchniej bieżni łożysk tocznych - przeglad, Dev. in Mech. Eng. 17(9), 103 (2021), doi: 10.37660/dme.2021.17.9.8

29. Aleksandrowicz, P. (2017). Verifying a truck collision applying the SDC method. $58^{\text {th }}$ International Conference of Machine Design Departments, 6-8.09.2017, Praque, Czech Republic, pp. 14-19.

30. M. Markiewicz, Ł. Muslewski, The impact of powering an engine with fuels from reneweble energy sources inclouding its softwere modification on a drive unit performance parameters. Sustainaibility 11, 23 (2019)

31. B. Landowski, Ł. Muslewski, Decision model of an operation and maintenance process of city buses, in Proceedings of $58^{\text {th }}$ International Conference of machine design departments, ICMD, 2017, Hnanice, Czech Rebublic

32. M. Markiewicz, Ł. Muślewski, M. Pająk, Impact biocomponent additive to diesel oil on values of selected functional parameters of transport means, Polish Journal of environmental studies, 29, 5 (2020) 
33. M. Markiewicz, Ł. Muślewski, Survey performence and emissionparameters of diesel engine poweredby diesel oil and fatty acid methyl esters using fuzzy logic techniques, Fuel, 277 (2020)

34. L. Knopik, K. Migawa, P. Kolber, Statistical analysis of parameters of rail vehicles, $22^{\text {nd }}$ International Conference on Engineering Mechanics, 9-12 May 2016, Svratka, Czech Republic (2016)

35. K. Migawa, A. Sołtysiak, M. Czyżewska, Method of assessment of the transport system functioning with the application of the simulation model of the operating process, $18^{\text {th }}$ International Conference Diagnostic of Machines and Vehicles, 12.12.2019 Bydgoszcz, Poland, MATEC Web of Conferences, vol. 302 (2019)

36. Martynyuk V., Liss, M.Wilczarska j.: Diagnostics of Corrosion Protection Potential for Electric Water Heaters. 18th International Conference Diagnostics of Machines and Vehicles, 2019.

37. J. Wilczarska, E. Kuliś, M. Łukasziewicz, Ł. Fornal, N. Dluhunovych, The assessment of the impact of the chosen exploational conditions of hydraulic arrangement on the working liquid condition. 17th International Conference Diagnostics of Machines and Vehicles Book SeriesMATEC Web of Conferences Volume182 Article Number01026 DOI10.1051/matecconf/201818201026, 2018

38. Żółtowski M., Liss M., Żółtowski B., Melcer J.: Truss harbor cranes modal design elements research, Polish Maritime Research, 22, 4(88), s. 84-92, 2015, p-ISSN: 1233258.

39. Kalaczynski T.; Martynyuk V.; Boiko J.; Matyukh S.; Petrashchuk S.: Exploitation aspects of diagnostic hydraulic and pneumatic systems of Multimedia Hybrid Mobile Stages, Published 2021, 19th International conference diagnostics of machines and vehicles hybrid multimedia mobile stage

40. M. Łukasiewicz, T. Kałaczyński, J. Musiał, J.Shalapko. Diagnostics of buggy vehicle transmission gearbox technical state based on modal vibrations, Journal of Vibroengineering, 16, Issue 6, Pages (2624-3168). (2014)

41. J. Musiał, M. Szczutkowski, R. Polasik, R.; T. Kałaczyński, The influence of hardness of cooperating elements on performance parameters of rolling kinematic pairs. In Proceedings of the 58th International Conference of Machine Design DepartmentsICMD 2017, Prague, Czech Republic, 6-8 September 2017; pp. 260-265 